\title{
KONSENTRASI BAHAN ORGANIK PADA PROSES PEMBUSUKAN \\ AKAR, BATANG DAN DAUN ECENG GONDOK (Eichhornia sp.) (SKALA LABORATORIUM)
}

\author{
Putri Cipta Pangestu, Suryanti, Prijadi Soedarsono ${ }^{1}$
}

Program Studi Manajemen Sumberdaya Perairan, Jurusan Perikanan

Fakultas Perikanan dan Ilmu Kelautan, Universitas Diponegoro

\begin{abstract}
ABSTRAK
Bahan organik pada tanah dapat terbentuk karena ada penimbunan dari sisa-sisa tanaman yang telah mengalami pelapukan, salah satunya dapat berasal dari akar, batang dan daun Eceng Gondok yang merupakan sumber primer bahan organik di perairan Rawa Pening. Tingginya konsentrasi bahan organik pada perairan Rawa Pening dapat terlihat dengan banyaknya populasi Eceng Gondok yang tumbuh di perairan tersebut serta penimbunan sisa-sisa tumbuhan pada perairan yang tidak termanfaatkan. Penumpukan sisa-sisa dari tanaman ini dikhawatirkan akan mengakibatkan perombakan bahan organik secara besar-besaran dan berdampak pada kondisi perairan yang terlalu subur (eutrofikasi).

Materi yang digunakan dalam penelitian ini adalah akar, batang dan daun Eceng Gondok. Metode pengambilan sampel yang digunakan adalah metode purposif sampling. Metode penelitian yang digunakan adalah metode eksperimen skala laboratorium. Rancangan percobaan yang digunakan adalah Rancangan Acak Lengkap (RAL) dengan 3 perlakuan dan 3 kali ulangan yaitu wadah percobaan yang masing-masing diisi akar, batang, dan daun Eceng Gondok. Data yang diamati meliputi konsentrasi bahan organik pada masing-masing bagian tumbuhan, rasio bobot masing-masing bagian tumbuhan, biomassa awal dan akhir sampel uji, kelarutan oksigen, suhu air, $\mathrm{pH}$ air serta $\mathrm{pH}$ tanah pada setiap wadah percobaan penelitian. Penelitian ini dilaksanakan pada bulan Juni hingga Juli 2013 di Laboratorium Hidrobiologi Fakultas Perikanan dan Ilmu Kelautan Universitas Diponegoro Semarang.

Hasil penelitian menunjukkan bahwa rata-rata konsentrasi bahan organik tertinggi terdapat pada wadah percobaan penelitian yang berisi akar Eceng Gondok dengan kisaran 50.25 - 57.3\%. Wadah yang berisi batang mengandung konsentrasi bahan organik dengan kisaran $48.87-55.84 \%$. Konsentrasi bahan organik terendah terdapat pada wadah yang berisi daun Eceng Gondok dengan kisaran 44.67 - 50.28\%. Biomassa Eceng Gondok mengalami reduksi setelah 4 minggu terbukti dari biomassa awal masing-masing 200 gr dan biomassa rata-rata akhir pada akar yaitu 96,6 g, pada batang 72,6 g dan pada daun 56,3 g. Berdasarkan hasil penelitian yang diperoleh maka dapat disimpulkan bahwa konsentrasi bahan organik tertinggi terdapat pada akar Eceng Gondok. Hasil analisis data konsentrasi bahan organik dengan Anova One Way terdapat perbedaan yang signifikan antara akar, batang dan daun diperoleh nilai signifikansi 0,00 $(\mathrm{p}<0.05)$. Bagian tumbuhan yang paling cepat terdekomposisi adalah daun Eceng Gondok.
\end{abstract}

Kata Kunci: Bahan Organik, Pembusukan, Eceng Gondok

\section{ABSTRACT}

Organic matters in soils formed from the remains of plants that have been subjected to weathering, one of the causes it came from roots, stems and leaves of Water Hyacinth which is the primary source of organic matter on Rawa Pening waters. The high concentration of organic matter in Rawa Pening waters can be seen with a large number of the population of Water Hyacinth which grow in these waters and the accumulation of fritter plants on waters are not utilized. The accumulation of this fritter plants worried to cause an overhaul of the organic matter in a big way and have an impact on the conditions of waters that are too infertile (eutrophication).

The materials used in this research were the roots, stems and leaves of the Water Hyacinth. The method of sampling which used was the purposive sampling method. The method of research which used was experimental laboratory-scale method. The experimental design which used was Complete Random Design (RAL) with 3 treatment and repeats in 3 times in the experiment containers, each filled with roots, stems, and leaves of the Water Hyacinth. Measured data include concentrations of organic matters in each part of the plant, the ratio of the weight of each piece, biomass of plant at beginning and at the end of the test sample, the dissolve of oxygen, water temperature, $\mathrm{pH}$ of the water and soil $\mathrm{pH}$ on each container of experimental research. This research was carried out in June to July 2013 at Hidrobiologi Laboratory of the Faculty of fisheries and Marine Science Diponegoro University Semarang.

The results showed that on average the highest concentration of organic matter found in the experiment research container that contains the roots of Water Hyacinth with a range of $50.25-57.3 \%$. Container of stems contains concentration of organic matter with the range of $48.87-55.84 \%$. The lowest concentration of the organic matters found in the container that contains the leaves of Water Hyacinth with a range of $44.67-50.28 \%$. Biomass of Water Hyacinth evident undergoes a reduction after 4 weeks of initial biomass is from each of 200 grams and average biomass of roots at the end is 96.6 grams, stems weighing 72,6 grams and leaves weighing 35 gram. Based on research results obtained then it can be concluded that the highest concentration of organic matter were at the roots of Water Hyacinth. Results of the analysis of the concentrations of organic matter data with the One Way Anova, there is a significant difference between the roots, stems and leaves of the retrieved value 0.00 significance $(p<0.05)$. The fastest plant parts which decomposed is Water Hyacinth leaves.

Keyword : Organic Matter, Decomposition, Water Hyacinth 


\section{Pendahuluan}

Eceng Gondok (Eichhornia sp.) merupakan tanaman gulma di wilayah perairan yang hidup terapung pada air yang dalam atau mengembangkan perakaran di dalam lumpur pada air yang dangkal. Eceng Gondok berkembang biak dengan sangat cepat, baik secara vegetatif maupun generatif. Dalam waktu 6 bulan pertumbuhan Eceng Gondok pada aeral 1 Ha dapat mencapai bobot basah sebesar 125 ton (Heyne, 1987). Pertumbuhan Eceng Gondok menyebabkan luas permukaan air Rawa Pening yang seluas 2670 Ha menyusut hingga 30\%. Jika kondisi ini dibiarkan dan ditambah potensi sedimentasi dari luruhan material sub daerah aliran sungai Rawa Pening di daerah hulu sebesar 778 ton/tahun, maka diprediksikan sebagian besar Rawa Pening akan menjadi daratan tahun 2020. Akar permasalahan Rawa Pening memang sedimentasi, yang dominan dari gulma air (Amariansah, 2010).

Eceng Gondok sebagai tumbuhan air pengganggu (gulma) sekarang ini banyak dimanfaatkan sebagai kerajinan tangan dan dapat juga dimanfaatkan sebagai pupuk sehingga tumbuhan ini dapat memberikan manfaat bagi masyarakat tidak hanya sebagai tumbuhan yang menjadi pengganggu. Pemanfaatan tersebut juga memunculkan permasalahan pada perairan. Bagian tumbuhan Eceng Gondok tidak semuanya dimanfaatkan, hanya diambil batangnya untuk dijadikan kerajinan tangan dan itupun tidak keseluruhan batang yang dimanfaatkan. Pada pemanenan sisa tumbuhan tersebut seperti daun, akar dan batang yang tidak terpakai langsung dibuang begitu saja pada perairan padahal dari observasi yang dilakukan, batang tumbuhan yang dipanen setiap harinya oleh masyarakat kurang lebih adalah 8 ton dimana batang yang diambil hanya $30 \%$ dari berat total sedangkan sisanya serta akar dan daun adalah $70 \%$ sehingga perlu diadakan pengelolaan lebih lanjut. Konsentrasi bahan organik yang ada pada masing-masing bagian tumbuhan Eceng Gondok tentunya berbeda baik daun, akar maupun batangnya. Sifat senyawa-senyawa organik pada umumnya tidak stabil dan mudah dioksidasi secara biologis atau kimia menjadi sanyawa stabil, antara lain menjadi $\mathrm{CO}_{2}$ dan $\mathrm{H}_{2} \mathrm{O}$. Proses inilah yang menyebabkan konsentrasi oksigen terlarut dalam perairan menurun dan hal yang menyebabkan permasalahan bagi kehidupan akuatik. Perubahan terhadap komposisi kimia bahan organik dari senyawa yang kompleks menjadi senyawa yang lebih sederhana terjadi pada proses tersebut. Proses yang terjadi dalam dekomposisi ataupun pembusukan yaitu perombakan sisa tanaman atau hewan oleh miroorganisme. Sisa-sisa tumbuhan yang ada pada perairan lama-kelamaan akan mengalami proses pembusukan dan akan mengendap pada dasar perairan. Hal tersebut, jika terus terjadi secara berkelanjutan dapat menimbulkan penumpukan sisa-sisa tanaman dan sangat dikhawatirkan dapat mengakibatkan terjadinya perombakan bahan organik secara besar-besaran. Pemeliharaan perairan secara baik sangatlah diperlukan untuk terus menjaga kestabilan perairan sehingga tidak mengakibatkan dampak buruk pada perairan yang dapat mengakibatkan kerugian bagi masyarakat dan lingkungan.

Tujuan dari penelitian ini adalah untuk mengetahui bagian mana dari tumbuhan Eceng Gondok (Eichhornia sp.) yakni daun, akar atau batang yang mengandung konsentrasi bahan organik paling tinggi melalui proses pembusukannya dilihat dari skala laboratorium serta bagian tumbuhan mana yang mengalami reduksi biomassa terbesar dalam proses dekomposisi. Hasil dari kegiatan penelitian ini dapat diimplementasikan pada perairan Rawa Pening sehingga dapat dijadikan acuan dalam menjaga keseimbangan ekosistem akuatik pada perairan Rawa Pening

\section{Materi dan Metode Penelitian}

\section{A. Materi Penelitian}

Materi yang digunakan dalam penelitian ini adalah Eceng Gondok yang diambil dari perairan Rawa Pening yaitu bagian daun, akar, dan batangnya sebagai sampel untuk diteliti. Adapun peralatan dan bahan pendukung dalam penelitian ini adalah 9 buah akuarium yang berfungsi sebagai wadah penempatan sampel (ukuran panjang $30 \mathrm{~cm}$, lebar $20 \mathrm{~cm}$ dan tinggi $20 \mathrm{~cm}$, serta volume akuarium sebesar 12 liter), DO meter yang berfungsi sebagai pengukur DO (oksigen terlarut), blower yang berfungsi untuk memberi aerasi, termometer yang berfungsi sebagai pengukur suhu air, $\mathrm{pH}$ meter yang berfungsi sebagai pengukur $\mathrm{pH}$ (air dan tanah), timbangan yang berfungsi untuk menimbang berat awal (akar, batang dan daun) dimana beratnya $\left(\mathrm{W}_{\mathrm{o}}\right)$ haruslah sama, botol sampel yang berfungsi sebagai wadah untuk menempatkan sampel saat diambil dari perairan, serta aqua dan tanah sekitar perairan Rawa Pening yang digunakan sebagai media pembusukan.

\section{B. Metode Pengambilan Sampel}

Metode pengambilan sampel yang digunakan adalah "Purposive Sampling" dimana sampel yang diambil memiliki spesifikasi tertentu yang dimiliki oleh sampel tersebut. Menurut Nasution (2009), purposive sampling memiliki keuntungan yakni sampel yang digunakan relevan dengan desain penelitian yang digunakan dan relatif mudah dan murah. Sampel yang diambil haruslah dapat bersifat representatif. Lokasi pengambilan sampel terletak pada titik koordinat $7^{\circ} 16^{\prime} 40.49^{\prime \prime} \mathrm{S}-110^{\circ} 26^{\prime} 19.59^{\prime \prime} \mathrm{T}$. Penetapan titik sampling berdasakan alasan yakni pada titik tersebut merupakan daerah dengan kondisi jumlah tutupan Eceng Gondok yang paling rapat. Titik sampling tersebut kini juga merupakan titik dimana masyarakat sekitar banyak mengambil Eceng Gondok untuk dimanfaatkan dan pada titik ini penimbunan sisa tumbuhan pada perairan terjadi secara langsung. 


\section{Metode Penelitian}

Metode penelitian yang digunakan adalah "Experimental Method". Menurut Notoatmodjo (2002), metode eksperimen adalah metode yang dilakukan untuk mengetahui suatu gejala atau pengaruh yang timbul, sebagai akibat dari adanya perlakuan tertentu. Ciri khusus dari penelitian eksperimen yaitu adanya percobaan. Percobaan itu berupa perlakuan atau intervensi terhadap suatu variabel dari perlakuan tersebut diharapkan terjadi perubahan atau pengaruh terhadap variabel yang lain.

Penelitian dilakukan menggunakan skala laboratorium dengan mengadakan percobaan pada kondisi dimana variabelnya dapat dikontrol. Selama proses pembusukan yang terjadi dalam akuarium akan dilakukan pengukuran konsentrasi bahan organik yang terkandung pada tanah setiap minggunya serta dilihat apa saja perubahan yang terjadi.

\section{Rancangan percobaan}

Rancangan percobaan dalam penelitian ini menggunakan Rancangan Acak Lengkap (RAL) dengan 3 perlakuan dimana pada masing-masing perlakuan dilakukan 4 kali pengulangan. Perlakuan pertama (A) adalah perlakuan media penelitian menggunakan akar Eceng Gondok. Perlakuan kedua (B) adalah perlakuan media penelitian menggunakan batang Eceng Gondok. Perlakuan ketiga (C) adalah perlakuan media penelitian menggunakan daun Eceng Gondok. Menurut Sastrosupadi (1995), rancangan acak lengkap dilakukan pada media yang homogen. Penerapan percobaan satu faktor dalam rancangan acak lengkap biasanya digunakan jika kondisi unit percobaan yang digunakan relatif homogen. Penerapan perlakuan terhadap unit percobaan dilakukan secara acak terhadap seluruh unit percobaan.

Pada penelitian ini dilakukan dengan 3 perlakuan dengan masing-masing 3 kali ulangan antara lain:

Perlakuan A : media dengan penggunaan akar eceng gondok.

Perlakuan $\mathrm{B} \quad$ : media dengan penggunaan batang eceng gondok.

Perlakuan $\mathrm{C} \quad$ : media dengan penggunaan daun eceng gondok.

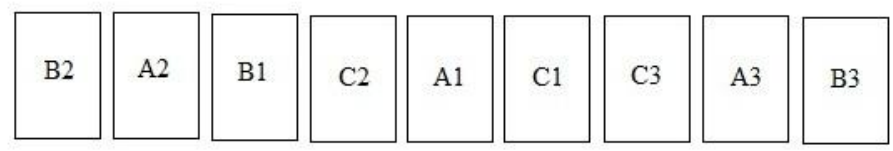

Gambar 1. Tata Letak Wadah Penelitian

\section{Prosedur Penelitian}

Prosedur penelitian dilakukan dengan pengambilan sampel akar, batang dan daun Eceng Gondok, pengambilan sampel tanah, penempatan materi sampel dengan berat masing-masing sampel 200 gram dan tanah setebal $5 \mathrm{~cm}$ ke dalam akuarium yang berisi $10 \mathrm{~L}$ air, pengamatan terhadap sampel selama proses pembusukan. Pengamatan konsentrasi bahan organik dilakukan sekali selama 4 minggu. Pengukuran kualitas air meliputi suhu air, DO, $\mathrm{pH}$ air dan $\mathrm{pH}$ tanah. Pada akhir penelitian dilakukan pengukuran terhadap biomassa Eceng Gondok yang tereduksi atau terdekomposisi dari biomassa awalnya.

\section{Prosedur pengujian konsentrasi bahan organik pada tanah}

Pengujian dan perhitungan konsentrasi bahan organik pada tanah dilakukan dengan prosedur yang meliputi pengambilan sampel tanah dari masing-masing akuarium (akar, batang dan daun), penimbangan sampel tanah seberat masing-masing 2 gram dan diletakkan dalam "crucible (cawan porselin)" bervolume $5 \mathrm{ml}$ yang sudah disterilkan dengan furnace hingga bersuhu $200{ }^{\circ} \mathrm{C}$, pembakaran sampel dalam "furnace (alat pengabuan)" yang suhunya telah mencapai $550^{\circ} \mathrm{C}$ selama 4 jam dan pengukuran selisih berat antara sampel kering sebelum dan sesudah dibakar dianggap bahan organik yang hilang.

$$
\begin{aligned}
& \text { Bahan organik }=\frac{(w t-c)-(w c-c) \times 100 \%}{w t-c} \\
& \text { Keterangan: } \\
& \mathrm{wt}=\text { berat total }(\text { crucible }+ \text { sampel) sebelum dibakar } \\
& \mathrm{wc}=\text { berat total }(\text { crucible }+ \text { sampel) setelah dibakar } \\
& \mathrm{c}=\text { berat "crucible" kosong }
\end{aligned}
$$

\section{Analisa data}

Analisis mengenai data hasil penelitian dilakukan di laboratorium, dimana data yang dianalisis adalah konsentrasi bahan organik yang terkandung dalam daun, akar, dan batang Eceng Gondok. Pengujian dilakukan pada tanah steril yang dipakai sebagai media pada proses pembusukan. Kandungan bahan organik dari tiap-tiap bagian Eceng Gondok akan mengendap atau terdekomposisi pada tanah yang dijadikan sebagai sustrat pada wadah pengujian. Tanah tersebut yang kemudian akan diuji pada laboratorium. 
Analisis data hasil penelitian menggunakan deskriptif. Menurut Subagyo (2003), yang dimaksud sebagai deskriptif adalah bagian mengenai pengumpulan data, penyajian, penentuan nilai-nilai statistika, pembuatan diagram atau gambar mengenai sesuatu hal, disini data yang disajikan dalam bentuk yang lebih mudah dipahami atau dibaca. Data konsentrasi bahan organik hasil laboratorium penelitian kemudian diuji dengan menggunakan One Way Anova taraf 5\%. Pengolahan data dengan menggunakan program statistik SPSS 16 juga dilakukan untuk mengetahui bagaimana perbedaan antara konsentrasi bahan organik pada akar, batang, dan daun Eceng Gondok yang diuji. Grafik perubahan konsentrasi bahan organik juga dibuat untuk memudahkan dalam pembacaan dan penganalisaan hasil uji.

\section{Hasil dan Pembahasan}

\section{Hasil analisa kandungan nitrat $\left(\mathrm{NO}_{3}\right)$}

Hasil analisis konsentrasi bahan organik akar, batang dan daun dalam satuan persen tersaji pada Tabel 1 di bawah ini.

Tabel 1. Data Konsentrasi Bahan Organik Akar, Batang dan Daun pada Tanah

\begin{tabular}{|c|c|c|c|c|c|}
\hline \multicolumn{2}{|c|}{ Bahan Organik } & $\begin{array}{c}\text { Minggu Ke-1 } \\
\text { 10 Juni } 2013(\%)\end{array}$ & Minggu Ke-2 & Minggu Ke-3 & Minggu Ke-4 \\
\hline \multirow[t]{3}{*}{ Akar } & A1 & 50.96 & 52.86 & 53.11 & 56.37 \\
\hline & $\mathrm{A} 2$ & 50.83 & 55.46 & 56.23 & 57.3 \\
\hline & A3 & 50.25 & 54.86 & 55.13 & 55.64 \\
\hline \multirow[t]{3}{*}{ Batang } & B1 & 49.23 & 51.45 & 52.28 & 55.84 \\
\hline & B2 & 48.87 & 52.05 & 52.98 & 53.08 \\
\hline & B3 & 49.89 & 52.55 & 54.1 & 54.91 \\
\hline \multirow[t]{3}{*}{ Daun } & $\mathrm{C} 1$ & 45.68 & 46.78 & 48.65 & 50.28 \\
\hline & $\mathrm{C} 2$ & 45.3 & 46.21 & 47.94 & 49.7 \\
\hline & C3 & 44.67 & 45.84 & 47.12 & 49.46 \\
\hline
\end{tabular}

Keterangan: $\quad$ A (Akar) ; B (Batang); C (Daun)

Berikut adalah grafik tren kenaikan konsentrasi bahan organik pada masing-masing bagian tumbuhan Eceng Gondok yang diuji.

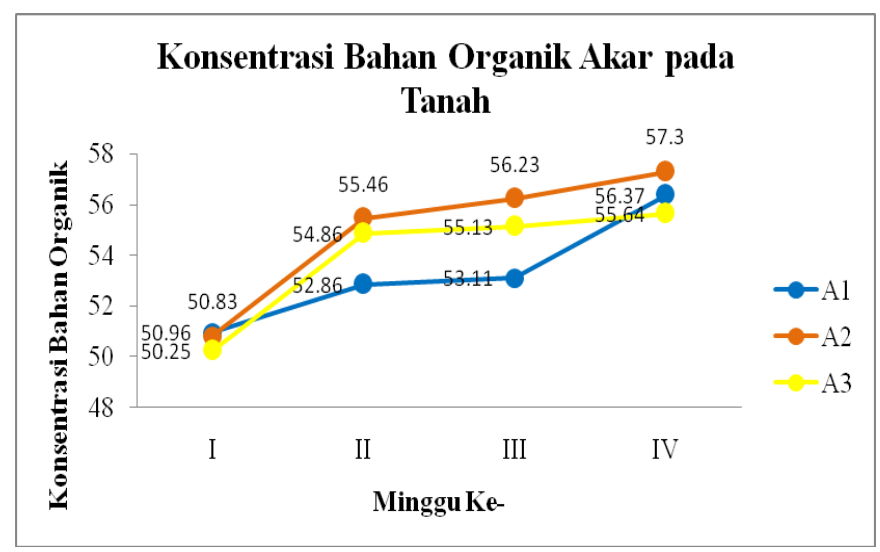

Gambar 1. Grafik Konsentrasi Bahan Organik Akar pada Tanah

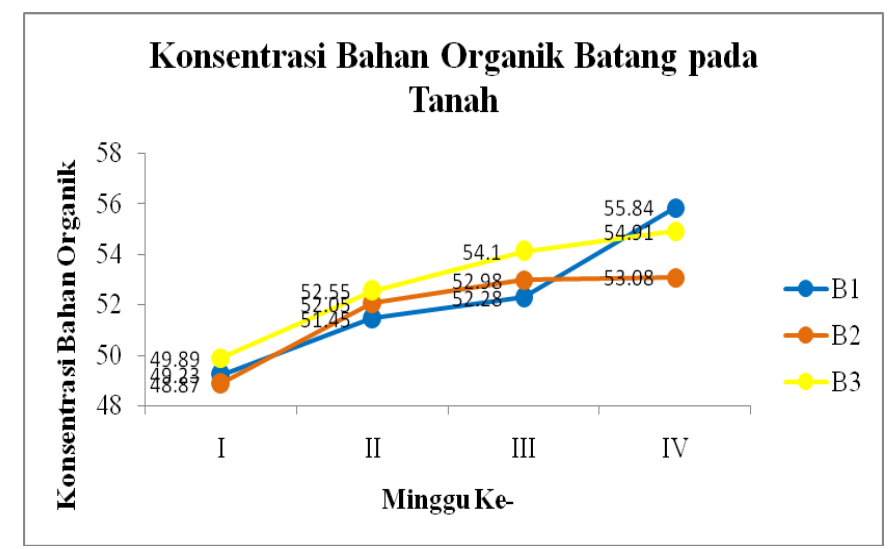

Gambar 2. Grafik Konsentrasi Bahan Organik Batang pada Tanah 


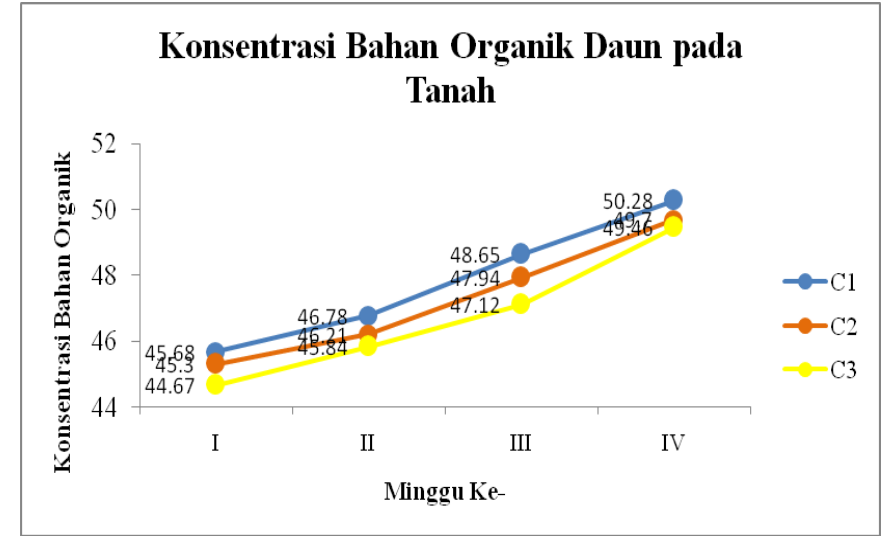

Gambar 3. Grafik Konsentrasi Bahan Organik Daun pada Tanah

Berdasarkan data hasil penelitian mengenai konsentrasi bahan organik pada akar, batang dan daun Eceng Gondok selama 4 minggu dapat dilihat bahwa konsentrasi bahan organik pada masing-masing bagian Eceng Gondok baik akar, batang dan daun terus mengalami peningkatan dari minggu ke minggunya. Sumber primer bahan organik pada tanah diketahui antara lain berasal dari akar, batang dan daun. Bagian akar memiliki konsentrasi bahan organik yang tertinggi dibandingan dengan batang dan daun yakni dengan kisaran konsentrasi antara 50.25 - 57.3 serta bagian daun yang memiliki konsentrasi bahan organik terendah yakni dengan kisaran konsentrasi antara 44.67 - 50.28. Sambodo (1996) menyatakan bahwa, akar merupakan salah satu sumber unsur hara N, P, S dan unsur mikro lainnya serta sumber energi bagi mikroorganisme pengurai. Dari kemampuan tersebut, akar dapat mempengaruhi unsur kimia pada tanah. Akar tumbuhan menyerap air dan berbagai mineral seperti nitrogen, fosfor, besi, kalsium dan kalium dari dalam tanah.

\section{Hasil pengukuran rasio berat akar, batang dan daun sampel}

Hasil pengukuran rasio berat akar, batang dan daun sampel tersaji pada Tabel 2 di bawah ini.

Tabel 2. Rasio Berat Akar, Batang dan Daun Eceng Gondok

\begin{tabular}{ccccccc}
\hline \multirow{2}{*}{ No. } & Berat Basah Total & Berat Kering Total Eceng & \multicolumn{3}{c}{ Sample $(\mathrm{Kg})$} & Rasio (\%) \\
\cline { 4 - 5 } & Eceng Gondok & Gondok setelah dijemur & Akar (A) & Batang (B) & Daun (C) & A : B :C \\
\hline 1 & 4.24 & 3.84 & 2.42 & 1.08 & 0.34 & $63: 28: 9$ \\
2 & 4.26 & 3.89 & 2.40 & 1.27 & 0.22 & $62: 32: 6$ \\
3 & 4.62 & 4.27 & 2.63 & 1.42 & 0.22 & $62: 33: 5$ \\
\hline
\end{tabular}

Hasil pengukuran terhadap rasio berat akar, batang dan daun dapat dilihat bahwa masing-masing tumbuhan memiliki bobot basah yang hampir sama yakni berkisar antara $4.24-4.26 \mathrm{~kg}$. Akar adalah bagian Eceng Gondok yang terberat dengan bobot lebih dari 50\% dari satu tanaman, sedangkan daun merupakan bagian yang teringan. Gopal dan Sharma (1981) menyatakan bahwa sistem perakaran Eceng Gondok umumnya 50\% lebih dari seluruh biomassa tumbuhan. Eceng Gondok yang tumbuh pada air yang kaya akan unsur hara mempunyai tangkai yang panjangnya lebih dari $100 \mathrm{~cm}$, tetapi akarnya pendek yaitu kurang dari $20 \mathrm{~cm}$, sedangkan dalam perairan yang miskin hara panjang tangkai kurang dari $20 \mathrm{~cm}$ tetapi akarnya lebih dari $60 \mathrm{~cm}$. Berdasarkan pernyataan tersebut maka dapat diketahui bahwa perairan Rawa Pening kaya akan unsur hara.

Hasil pengukuran biomassa sampel Eceng Gondok (Eichhornia sp.)

Hasil pengukuran biomassa Eceng Gondok (Eichhornia sp.) pada media penelitian tersaji pada Tabel 3 di bawah ini.

Tabel 3. Biomassa Awal dan Akhir Akar, Batang serta Daun Eceng Gondok

\begin{tabular}{cccc}
\hline \multirow{2}{*}{ Eceng Gondok } & \multicolumn{2}{c}{ Biomassa Eceng Gondok $(\mathrm{g})$} \\
\cline { 2 - 4 } Akar & $\mathrm{A} 1$ & $\mathrm{~W}_{\text {awal }}$ & $\mathrm{W}_{\text {akhir }}$ \\
& $\mathrm{A} 2$ & 200 & 90 \\
\multirow{5}{*}{ Batang } & $\mathrm{A} 3$ & 200 & 90 \\
& $\mathrm{~B} 1$ & 200 & 110 \\
& $\mathrm{~B} 2$ & 200 & 75 \\
\multirow{5}{*}{ Daun } & $\mathrm{B} 3$ & 200 & 70 \\
& $\mathrm{C} 1$ & 200 & 73 \\
& $\mathrm{C} 2$ & 200 & 50 \\
& $\mathrm{C} 3$ & 200 & 65 \\
\end{tabular}


Hasil pengukuran biomassa pada akar, batang dan daun Eceng Gondok dapat dilihat bahwa secara keseluruhan mengalami reduksi bobot yang signifikan dari massa awal 200 gram hingga mengalami penurunan dengan kisaran massa akhir 56.3-96.6 gram. Hal tersebut dikarenakan pada saat proses pembusukan berlangsung sisa tanaman Eceng Gondok berupa akar, batang dan daun mengalami penguraian bahan-bahan organik yang terkandung dalam masing-masing bagian kemudian mengendap di tanah sehingga mengakibatkan adanya reduksi terhadap massa akar, batang dan daun. Pada akuarium penelitian dapat diketahui bahwa daun (C3) merupakan bagian Eceng Gondok yang paling besar mengalami penurunan massa yaitu sebesar 146 gram. Setyo (2006) menyatakan bahwa daun merupakan bahan yang mudah terdekomposisi selanjutnya menurut Rachman S. (2008) daun mengandung protein yang mudah terdekomposisi menjadi fosfat $\left(\mathrm{PO}_{4}\right)$, sulfat $\left(\mathrm{SO}_{4}\right)$, nitrat $\left(\mathrm{NO}_{3}\right)$, amoniak $\left(\mathrm{NH}_{3}\right)$, karbon dioksida $\left(\mathrm{CO}_{2}\right)$ dan air $\left(\mathrm{H}_{2} \mathrm{O}\right)$.

\section{Faktor fisika dan kimia yang mempengaruhi proses pembusukan}

Hasil pengukuran terhadap faktor fisika dan kimia yang mempengaruhi proses pembusukan tersaji pada Tabel 4 di bawah ini.

Tabel 4. Faktor Fisika dan Kimia yang Mempengaruhi Proses Pembusukan

\begin{tabular}{cc}
\hline Faktor Fisika dan Kimia yang Mempengaruhi & Kisaran \\
\hline Oksigen Terlarut (DO) & $1.03-2.90 \mathrm{mg} / \mathrm{l}$ \\
Suhu Air & $22.7-24^{\circ} \mathrm{C}$ \\
pH Air & $6.3-7$ \\
pH Tanah & $5-5.5$ \\
\hline
\end{tabular}

Hasil pengamatan kandungan oksigen terlarut (DO) pada air dalam akuarium selama proses pembusukan dapat dilihat bahwa nilai DO mengalami perubahan dengan kisaran $1.03-2.90 \mathrm{mg} / \mathrm{l}$ atau masih dalam kisaran normal. Masing-masing bagian tumbuhan secara rata-rata juga mengalami penurunan kadar DO dari minggu ke minggunya. Oksigen yang terlarut mempengaruhi kecepatan dari proses dekomposisi sisa tanaman, untuk itu penting untuk menjaga kandungan oksigen terlarut pada akuarium peneltian. Metacalf dan Eddy, 1979 dalam Rahmaningsih (2006) menyatakan bahwa laju pertumbuhan bakteri nitrifikasi dipengaruhi oleh konsentrasi oksigen terlarut (DO). Pada oksigen terlarut kurang dari $0,5 \mathrm{mg} / \mathrm{l}$ laju pertumbuhannya minimum. Proses tersebut dapat berjalan dengan baik jika konsentrasi oksigen sekitar 2,0 mg/l selanjutnya menurut Effendi (2003), dalam kegiatan dekomposisi dan oksidasi kadar oksigen yang terlarut dapat berkurang. Konsentrasi DO terendah pada penelitian terdapat pada akuarium berisi daun Eceng Gondok, dan dapat ditarik kesimpulan bahwa sisa daun pada perairan Rawa Pening lebih berpotensi menurunkan kadar DO. Berdasarkan pada kondisi akuarium penelitian, maka dapat digambarkan bagaimana kondisi kandungan oksigen telarut pada lokasi pengambilan sampel dimana pertumbuhan tanaman Eceng Gondok pada daerah tersebut sangat rapat sehingga dapat menurunkan konsentrasi oksigen terlarutnya.

Hasil pengamatan terhadap suhu air yang mempengaruhi proses pembusukan didapatkan nilai suhu rata-rata berkisar antara $22.7-24^{\circ} \mathrm{C}$. Menurut Effendi (2003), proses dekomposisi berlangsung pada kondisi yang hangat yaitu $5-35^{\circ} \mathrm{C}$. Pada masing-masing akuarium yang berisi akar, batang dan daun secara keseluruhan berada pada kisaran tersebut, sehingga proses dekomposisi pada akuarium penelitian dapat berlangsung dengan baik. Berdasarkan data hasil penelitian mengenai kandungan $\mathrm{pH}$ air dan tanah dalam akuarium selama proses pembusukan dapat dilihat bahwa nilai $\mathrm{pH}$ air dan tanah cukup konstan. Kisaran $\mathrm{pH}$ air pada akuarium adalah 6.3 - 7. Suhardi (1991) menyatakan bahwa kisaran pH optimum untuk Eceng Gondok adalah 6 - 8 dan selanjutnya menurut Effendi (2003), proses dekomposisi bahan organik berlangsung lebih cepat pada kondisi $\mathrm{pH}$ netral dan alkalis karena bakteri dekomposer dapat tumbuh dengan baik. Kisaran $\mathrm{pH}$ tanah pada akuarium adalah 5-5.5. Agus dan Subiksa (2008) menyatakan bahwa pH tanah gambut di Indonesia secara umum berkisar antara $3-5$. Keberadaan bahan yang mengandung lignin tinggi menyebabkan tanah gambut memiliki karakteristik $\mathrm{pH}$ yang masam.

Hasil uji normalitas dan homogenitas data terhadap data konsentrasi bahan organik akar, batang dan daun dengan selang kepercayaan $95 \%$ menunjukkan bahwa data hasil penelitian berasal dari populasi yang terdistribusi normal $(\mathrm{p}>0,05)$. Hasil analisis data one way anova menyatakan bahwa konsentrasi bahan organik pada akar, batang dan daun memiliki perbedaan yang nyata atau signifikan dengan taraf signifikansi 0.00 . Perbedaan tersebut juga dapat dilihat bahwa bagian akar yang memiliki konsentrasi bahan organik tertinggi dan bagian daun memiliki konsentrasi terendah. Kisarannya adalah antara $50.28-57.30 \%$. Reynold (1983) dalam Rosmarkam dan Yuwono (2002) menyatakan bahwa kandungan bahan organik dalam tanah dengan kisaran $\geq 35 \%$ tergolong sangat tinggi.

\section{Kesimpulan}

Kesimpulan yang didapat dari penelitian ini antara lain:

1. Konsentrasi bahan organik akar, batang dan daun Eceng Gondok (Eichhornia sp.) yang terkandung dalam tanah pada proses pembusukannya menggambarkan bahwa akar Eceng Gondok memiliki konsentrasi bahan organik yang tertinggi dengan kisaran antara 50.25-57.3\%; dan 
2. Bagian dari tumbuhan Eceng Gondok yang paling cepat mengalami proses dekomposisi adalah daun yang tereduksi biomassanya rata-rata sebesar 143.67 gram dari biomassa awalnya.

\section{Ucapan Terima Kasih}

Ucapan terima kasih ditujukan kepada Ibu Dr. Ir. Suryanti, M.Pi dan Bapak Ir. Prijadi Soedarsono, M.Sc. atas bimbingannya dalam penyusunan jurnal penelitian ini.

\section{Daftar Pustaka}

Agus, F dan I. M. Subiksa. 2008. Lahan Gambut: Potensi untuk Pertanian dan Aspek Lingkungan. Balai Penelitian Tanah dan World Agroforestry Center. Bogor.

Amariansah, W. 2010. Bangunan Pengendali Penyebaran Eceng Gondok di Rawa Pening. Jurnal Teknik Sipil. 21 hal.

Effendi, H. 2003. Telaah Kualitas Air. Bagi Sumberdaya dan Lingkungan Perairan. Kanisius. Yogyakarta.

Gopal, B. and Sharma. 1981. Water Hyacinth (Eichhornia crassipes) (Malt Solms) The Most Troublesome Weed of The World. Hindasia. New Delhi.

Heyne, K. 1987. Tumbuhan Berguna Indonesia Jilid II. Badan Penelitian dan Pengembangan Kehutanan. Departemen Kehutanan. Bogor.

Nasution, S. 2009. Metode Research (Penelitian Ilmiah). Bumi Aksara. Jakarta.

Notoatmodjo, S. 2002. Metodologi Penelitian Kesehatan. Rineka Cipta. Jakarta.

Rachman S. 2008. Penerapan Pertanian Organik-Pemasyarakatan dan Pengembangannya. Kanisius. Yogyakarta.

Rahmaningsih, H. D. 2006. Kajian Penggunaan Eceng Gondok (Eichhornia crassipes) pada Penurunan Senyawa Nitrogen Enfluen Pengolahan Limbah Cair PT Capsugel Indonesia. Fakultas Teknologi Pertanian ITB. Bogor.

Rosmarkam, A. dan N. M. Yuwono. 2002. Ilmu Kesuburan Tanah. Kanisius. Yogyakarta.

Sambodo, J. 1996. Memahami Dunia Tersembunyi: Kehidupan Tumbuhan. PT Elex Media Komputindo. Jakarta.

Sastrosupadi, A. 1995. Rancangan Percobaan Praktis untuk Bidang Pertanian. Kanisius. Yogyakarta.

Setyo, P.N. 2006. Mengolah Sampah untuk Pupuk dan Pestisida Okganik. Penebar Swadaya. Jakarta.

Subagyo, P. 2003. Statistik Deskriptif. BPFE. Yogyakarta.

Suhardi. 1991. Penunjuk Laboratorium Analisa dan Penanganan Limbah. Universitas Gajah Mada. Yogyakarta. 